\title{
WILEY
}

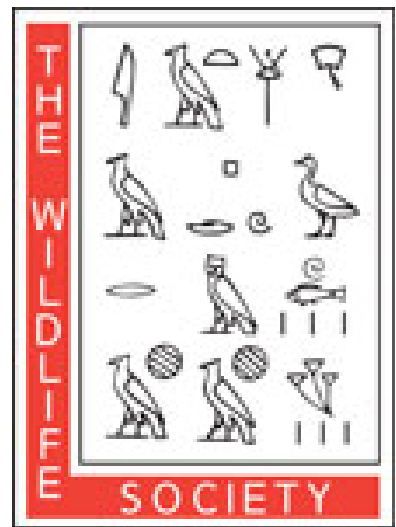

\section{Allen Press}

Woodpecker Abundance and Habitat Use in Mature Balsam Fir Forests in Newfoundland Author(s): Michael A. Setterington, Ian D. Thompson and William A. Montevecchi Source: The Journal of Wildlife Management, Vol. 64, No. 2 (Apr., 2000), pp. 335-345 Published by: Wiley on behalf of the Wildlife Society

Stable URL: http://www.jstor.org/stable/3803231

Accessed: $25 / 06 / 2013$ 11:17

Your use of the JSTOR archive indicates your acceptance of the Terms \& Conditions of Use, available at http://www.jstor.org/page/info/about/policies/terms.jsp

JSTOR is a not-for-profit service that helps scholars, researchers, and students discover, use, and build upon a wide range of content in a trusted digital archive. We use information technology and tools to increase productivity and facilitate new forms of scholarship. For more information about JSTOR, please contact support@jstor.org. 
conservation implications. Cambridge University Press, New York, New York, USA.

WETMORE, A. 1915. Mortality among waterfowl around Great Salt Lake, Utah. U.S. Department of Agriculture Bulletin 217.

1918. The duck sickness in Utah. U.S. Department of Agriculture Bulletin 672.

- 1919. Lead poisoning in waterfowl. U.S. Department of Agriculture Bulletin 93.

White, R. M. 1990. The great climate debate. Scientific American 263:36-43.

WHITMAN, W. R. 1976. Impoundments for waterfowl. Canadian Wildlife Service Occasional Paper 22.
Williams, B. K., M. D. KonefF, AND D. A. SMith. 1999. Evaluation of waterfowl conservation under the North Ameican Waterfowl Management Plan. Journal of Wildlife Management 63:417-440.

Williams, C. S., AND W. H. Marshall. 1937. Goose nesting studies on Bear River Migratory Bird Refuge. Journal of Wildlife Management 1:7786.

Wobeser, G. A. 1997. Diseases of wild waterfowl. Plenum Press, New York, New York, USA.

WRIGHT, B. S. 1954. High tide and an east wind, the story of the black duck. Stackpole, Harrisburg, Pennsylvania, USA.

\title{
WOODPECKER ABUNDANCE AND HABITAT USE IN MATURE BALSAM FIR FORESTS IN NEWFOUNDLAND
}

\author{
MICHAEL A. SETTERINGTON, ${ }^{1}$ Biopsychology Programme, Memorial University of Newfoundland, St. John's, NF A1B 3X9, \\ Canada \\ IAN D. THOMPSON, ${ }^{2}$ Canadian Forest Service, 1219 Queen Street East, Sault Ste. Marie, ON P6A 5M7, Canada \\ WILLIAM A. MONTEVECCHI, Biopsychology Programme, Memorial University of Newfoundland, St. John's, NF A1B 3X9, \\ Canada
}

\begin{abstract}
Availability of the oldest age-class of balsam fir (Abies balsamea) forest, the major forest type of western Newfoundland, is declining through logging, insect effects, and management for a 60-year harvest rotation. Loss of old-growth balsam fir forests may limit the availability of woodpecker habitat if nesting trees and feeding substrates are most abundant in these later successional stages. We assessed abundance of blackbacked woodpeckers (Picoides arcticus), downy woodpeckers (P. pubescens), and hairy woodpeckers (P. villosus) in 10 stands in each of 3 forest age classes $(40-59,60-79$, and $>80 \mathrm{yr})$ of balsam fir in western Newfoundland. For each stand, we quantified 10 habitat variables that may have influenced habitat use by woodpeckers. Blackbacked woodpeckers were almost exclusively found in $>80$-year-old forests. Density of black-backed woodpeckers was significantly related to number of large snags, but negatively to the total number of dead stems. Downy woodpeckers were common and similarly distributed among the 3 forest age classes, and hairy woodpeckers were uncommon and only observed in the 40- and 60-year age classes. Downy and hairy woodpeckers were significantly associated with the number of white birch snags in the stands, a resource that declined with forest age. A reduction in the amount of forest in the oldest age class is probably reducing the population of black-backed woodpeckers in western Newfoundland. We recommend a series of fixed-width transects, coupled with point counts using call broadcasts, as an effective means of surveying woodpeckers. Forest managers must maintain large areas of old forests, temporally and spatially, to maintain black-backed woodpeckers in Newfoundland.
\end{abstract}

JOURNAL OF WILDLIFE MANAGEMENT 64(2):335-345

Key words: Abies balsamea, balsam fir, black-backed woodpecker, downy woodpecker, hairy woodpecker, Newfoundland, old growth, Picoides arcticus, Picoides pubescens, Picoides villosus.

Concern over loss of old-aged forests is common throughout North America (Leverett 1996). Forests dominated by balsam fir are the major forest types of Newfoundland, Canada

\footnotetext{
${ }^{1}$ Present address: AXYS Environmental Consulting, P.O. Box 2240, 2045 Mills Road West, Sidney, BC V8L 3S8, Canada.

${ }^{2}$ E-mail: ian.thompson@nrcan.gc.ca
}

(Damman 1983), but the amount of natural-origin, old balsam fir forest has been reduced primarily through clearcut logging and a lethal outbreak of hemlock looper (Lambdina fiscellaria) in 1987 (Thompson 1991). On the western part of the island, about $24 \%$ of the area described by Rowe (1972) as the Corner Brook boreal forest region (region B28.b) is currently in the oldest age class $(>80 \mathrm{yr})$, whereas about $17 \%$ exists 
in age class 60-79 years as second-growth forests (i.e., regrowth following logging). Within a decade, much of the $>80$-year age class will either be harvested or die, because balsam fir is a short-lived species. The relatively small area of forest in the current 60-79-year age class, that will become the next old-growth forest, coupled with ongoing harvesting of this age class, will result in considerably less old forest within 10-20 years. Harvesting some of the next 60-79-year age class (now 40-59 yr old) for pulpwood is also inevitable over the next decade, particularly since many of these stands were pre-commercially thinned to enable more rapid growth than in self-thinning stands. Some $<80$-year-old stands are already being harvested because of their accessibility and high rates of regrowth on productive forest sites. Haney and Schaadt (1996) noted that the truncation of forest age rarely is discussed with respect to wildlife responses, but a rotation age of 60 years for balsam fir forests may have negative consequences for sustaining biological diversity. Thompson and Curran (1995) showed that there were differences in the mammalian communities between $>80$-year-old uncut and 60 79-year-old second-growth stands in Newfoundland, with marten (Martes americana) and field voles (Microtus pennsylvanicus) only found in the old forests.

Newfoundland's balsam fir forests differ from most boreal forest types because they do not require fire to naturally regenerate. These ecosystems do not undergo dramatically different successional stages (i.e., in terms of species composition) following logging (Bakuzis and Hansen 1965). Instead, forests of all ages are dominated by balsam fir at decreasing densities with age, ranging from $>20,000$ stems/ha as shrubs, to older stands of approximately 2,000 stems/ha (Meades and Moores 1989, Thompson and Curran 1995). Balsam fir stands are shortlived and the old-growth stage may only last 2030 years, and trees $>100$ years are exceptional.

Cavity-nesters are a group of species that may be especially affected by a decline in the oldest age classes of forest, because it is these stands that maintain high densities of large snags (Thomas et al. 1988, Angelstam and Mikusinski 1994, Haney and Schaadt 1996). Sufficiently large snags are important for nesting by most woodpecker species (Evans and Conner 1979, McComb et al. 1986), and availability of such trees may limit some woodpecker populations
(Wood et al. 1985, Bull and Holthausen 1993). Guidelines have been established by various management agencies to provide suitable cavity-nesting habitat in commercial forests (Thomas et al. 1979). Our study reports on the woodpecker species that breed in balsam fir ecosystems of western Newfoundland: black-backed woodpecker, three-toed woodpecker (Picoides tridactylus), downy woodpecker, and hairy woodpecker. Northern flickers (Colaptes auratus) are also found in Newfoundland (Mactavish et al. 1999), but are usually associated with clearings and edges rather than continuous forest.

Black-backed woodpeckers and three-toed woodpeckers are most frequently reported in spruce (Picea spp.) and pine forests (Pinus spp.; Bock and Bock 1974). However, these types are rare in western Newfoundland, except for lowland black spruce (Picea mariana) that occurs in bogs and small tracts of wet-site forests. Black-backed woodpeckers typically are uncommon throughout their range, but may become locally abundant in recently burned forests (Villard and Beninger 1993, Villard 1994, Hutto 1995). In eastern North America, black-backed woodpeckers are more common than threetoed woodpeckers, often greatly out-numbering the latter during population peaks in preferred habitats (Yunick 1985). Downy woodpeckers and hairy woodpeckers are common throughout the forests of insular Newfoundland (Mactavish et al. 1999). Elsewhere, downy woodpeckers are reported to be restricted to areas of moist deciduous growth in mixed-coniferous forests (Short 1982). Recently, Whitaker and Montevecchi (1997) and Thompson et al. (1999) reported studies of songbirds from western Newfoundland and found that woodpecker species occurred in low abundances. Our research followed the latter study to assess possible differences in use by woodpeckers among stands in the various mature age classes in balsam fir forests. We were particularly interested in blackbacked woodpeckers because this species appeared to be old-growth dependent (Thompson et al. 1999), possibly making them susceptible to decline under a short-rotation management regime, where old balsam fir forests would be in short supply. Our objective was to survey and compare abundances of woodpecker species among mature age classes of balsam fir forests. We were especially interested in differences in woodpecker species and abundances between 
uncut $>80$-year-old forests and those in the oldest second-growth forests, which were at rotation age. We predicted that the highest densities of all the woodpecker species would be achieved in the oldest forest stands because of expected higher snag density.

\section{STUDY AREA}

Our study area was approximately $2,500 \mathrm{~km}^{2}$ of the Newfoundland west coast balsam fir forest type (B. 28b, Rowe 1972). It extended about $140 \mathrm{~km}$ north to south from the upper Humber River Valley $\left(49^{\circ} 37^{\prime} \mathrm{N}, 57^{\circ} 12^{\prime} \mathrm{W}\right)$, to immediately south and west of Little Grand Lake $\left(48^{\circ} 35^{\prime} \mathrm{N}, 57^{\circ} 50^{\prime} \mathrm{W}\right)$. The area had a cold, wet maritime climate, received about $1,300 \mathrm{~mm}$ of precipitation annually, and had an average annual frost-free period of 130 days (Banfield 1983). Located on a coastal plain west of the Long Range Mountains, the area had a rolling to rugged topography with numerous bedrock outcrops and interrupted drainages. Shallow, coarse, podsol soils were characterized by a high cobble component, and supported forests dominated by balsam fir. Scattered admixtures of white birch, trembling aspen (Populus tremuloides), and white spruce (Picea glauca) occurred on suitable sites, and larch (Larix laricina) and black spruce dominated on wetter sites and riparian areas.

\section{METHODS}

\section{Stand Selection}

We chose stands based on age and dominant tree species as determined from forest resource inventory mapping and industrial cutting records. Forest resource inventory procedures define a forest stand as being sufficiently uniform in age, species composition, and site type that it can be distinguished from adjacent stands. Our 30 stands were randomly selected, but choice was constrained by several criteria (see below) and stand accessibility. We pooled stands ranging in age from 40-47 years since logging into age class $40(n=10)$; those stands 52-73 years since logging were our age class $60(n=$ 10 ); and uncut stands, ranging from 77-87 years old, were our age class $80(n=10)$. We based stand ages on the mean of 20 randomly sampled dominant trees per stand. To eliminate possible area effects, selected stands were part of larger forest complexes of a minimum size of $3 \mathrm{~km}^{2}$, and not fragments isolated by edges of recently logged stands. However, one edge of most stands was adjacent to a road. It was important that our samples were taken from continuous forests because some woodpecker species have large home ranges (e.g., reported black-backed woodpecker home ranges are 72-328 ha [Winkler et al. 1995]). Our uncut stands near Little Grand Lake were distinctly separated by lakes and bogs, but were necessarily located within a radius of a few kilometers of each other as this was the only remaining uncut forest on our study area.

\section{Stand Characterization}

We characterized forest stands by density and species composition of woody vegetation including: trees, canopy cover, standing dead trees, and woody debris on the ground. Stem density of trees (diameter at breast height [dbh] $>10 \mathrm{~cm}$ ), small trees $(>3 \mathrm{~m}$ tall and $<10 \mathrm{~cm}$ $\mathrm{dbh}$ ), and dead trees or snags (stem height $>3$ $\mathrm{m})$ was measured using the plotless point-distance technique of Batcheler (1975) at 100 random points per stand. We recorded height, dbh, and species for each stem. These data provided the following variables: stem density, species stem densities, mean tree height, coefficient of variation in tree height (a measure of canopy profile), and proportion of trees in various stem size classes (e.g., snags $>20 \mathrm{~cm}$ ). Woody debris (number of logs $>10 \mathrm{~cm}$ diam) was assessed on 10 equilateral triangular $90 \mathrm{~m}$ transects $(30 \mathrm{~m}$ on a side) per stand (McRae et al. 1979) on a subsample of 5 stands in each age class that were used for a study of small mammals (Thompson and Curran 1995). Canopy closure was measured with a forest densiometer by taking 4 readings at each of 50 random points per stand. We compared individual habitat variables among forest age classes by 2-way ANOVA to characterize differences among stand age classes. We then used least significant difference tests (LSD; Day and Quinn 1989) to test for differences between pairs of forest age classes.

\section{Surveys for Woodpeckers}

We assumed that where woodpecker density was highest, there must be some quality of habitat that is beneficial to woodpecker populations (Anderson and Gutzwiller 1994). However, we concur with Van Horne (1983) that unless productivity is measured, the value of selected habitats to fitness cannot be certain.

Each of our 30 stands contained 5 survey points located $200 \mathrm{~m}$ apart to avoid counting 
the same birds more than once. To ensure that all birds heard drumming or calling were within the stand being measured, all points were $>100$ $\mathrm{m}$ from stand edges. We surveyed each stand twice during a 6-week period from 27 May to 7 July 1991-94. Surveys commenced $30 \mathrm{~min}$ after sunrise and were completed before 1030 . The same 2 observers surveyed the same stands in 1991-92. One of those observers also surveyed the same stands in 1993-94, but a different observer surveyed the other stands in those years. Two sites were visited each day by each of the 2 observers.

It is difficult to survey woodpeckers accurately because of their large home ranges and often secretive nature. We used a point-count method which provided a measure of relative abundance (Blondel et al. 1981, Bibby et al. 1992; D. A. Welsh, Canadian Wildlife Service, personal communication). In 1993-94, we also broadcasted calls and drumming of woodpeckers to attract birds (Mosher et al. 1990), in the order of black-backed, three-toed, downy and hairy woodpeckers (Library of Natural Sounds, Cornell Laboratory of Ornithology, Ithaca, New York, USA). Calls included a mixture of drumming and vocalizations that are associated with territorial defense (Short 1982). This method was used in an attempt to attract any woodpeckers that may otherwise have remained undetected during a normal point count (Johnson et al. 1981, Marion et al. 1981).

In 1991-92, we recorded woodpeckers heard or seen during a $10 \mathrm{~min}$ period. In 1993-94, the first 2 min of the 10-min survey were spent listening for birds. After the initial $2 \mathrm{~min}$, we broadcasted woodpecker calls using a durable and compact monaural tape system with a 35 $\mathrm{dB}$ signal to noise ratio, and amplified through speakers with a frequency range of $150-15,000$ Hz. Each call was broadcast for 1-min intervals, with 1 min of silence between each call to allow the observer to record responses. During call broadcasting, we continuously scanned for woodpeckers. While there are identifiable differences in the drumming and calling of the different species of woodpeckers (Short 1982, Ellison 1992, Kaufman 1993), we relied on visual identification for confirmation of species and sex. We did not conduct surveys during periods of strong winds $(>20 \mathrm{~km} / \mathrm{hr})$ or heavy rain, because these conditions may have affected observer performance or bird behavior (Dawson 1981).

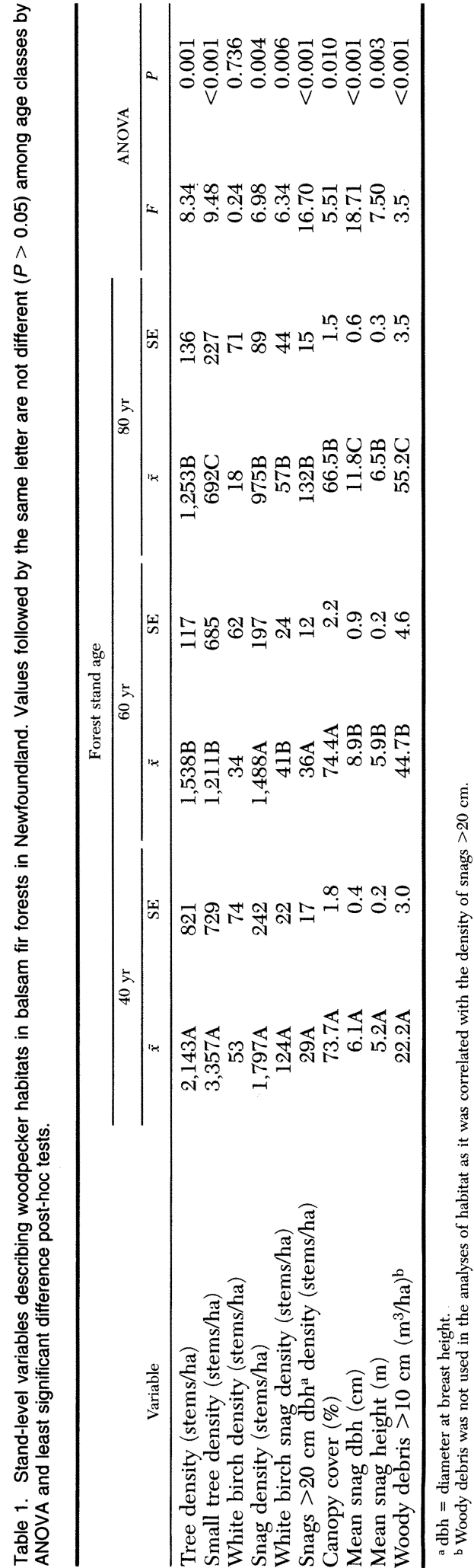


Table 2. Mean IPA values (number of presumed pairs) for woodpeckers from all stands ( $n=30$ stands/yr), by year and observer method (point counts and response to broadcast of woodpecker calls), from balsam fir forests of western Newfoundland, 199194. Means followed by the same letter are not different across rows $(P>0.05)$.

\begin{tabular}{|c|c|c|c|c|c|c|c|c|}
\hline \multirow[b]{3}{*}{ Species } & \multicolumn{4}{|c|}{ Point count } & \multicolumn{4}{|c|}{ Call broadcast-point count } \\
\hline & \multicolumn{2}{|c|}{1991} & \multicolumn{2}{|c|}{1992} & \multicolumn{2}{|c|}{1993} & \multicolumn{2}{|c|}{1994} \\
\hline & $\bar{x}$ & SE & $\bar{x}$ & SE & $\bar{x}$ & SE & $\bar{x}$ & $\mathrm{SE}$ \\
\hline Black-backed woodpecker & $0.13 \mathrm{~A}$ & 0.06 & $0.32 \mathrm{~A}$ & 0.12 & $0.17 \mathrm{~A}$ & 0.09 & 0.0 & \\
\hline Downy woodpecker & $0.50 \mathrm{~A}$ & 0.15 & $0.30 \mathrm{~A}$ & 0.12 & $0.92 \mathrm{~B}$ & 0.19 & $0.70 \mathrm{~B}$ & 0.17 \\
\hline Hairy woodpecker & $0.03 \mathrm{~A}$ & 0.03 & $0.08 \mathrm{~A}$ & 0.06 & $0.08 \mathrm{~A}$ & 0.04 & 0.0 & \\
\hline Northern three-toed woodpecker & 0.0 & & 0.0 & & 0.03 & 0.03 & 0.0 & \\
\hline
\end{tabular}

\section{Data Analyses}

We translated individual counts into numbers of pairs if a drumming male, pair, occupied nest, or a family group were observed (similar to the calculation of an 'Indice Ponctual D'Abondance' [IPA], Blondel et al. 1981). Single birds seen or heard calling were scored as 0.5 pairs (Blondel et al. 1981). We used the highest of the counts from the 8 visits to each point in each stand over the 4 years of the study as the measure of abundance for each species by stand. Prior to analysing differences in woodpecker occurrence among forest age classes, we compared the results of the 2 survey methods (point count and call broadcast) because they may have resulted in different numbers of birds detected. Results for downy woodpeckers were sufficiently numerous to allow analysis by parametric statistics. Log-transformed IPA values for downy woodpeckers were compared by 2 way ANOVA using the 2 main effects of year and survey method. We visually examined residual plots to ensure normality (Draper and Smith 1981). We used Kruskal-Wallis tests to assess among-year changes in numbers of hairy woodpeckers and black-backed woodpeckers that may have been related to the 2 survey methods, because of low numbers and their uneven dis- tribution. There were too few observations of three-toed woodpeckers to permit analysis.

We assessed importance of habitat variables to use of forest stands by woodpeckers through regression modeling. We examined for correlations among habitat variables, and eliminated 1 of the pair if $r>0.60$, prior to relating woodpecker species abundance to habitat values within stands by multiple regression models. Sufficient observations enabled linear regression modeling for downy woodpeckers. Logistic regression was performed based on presence or absence within individual stands for blackbacked woodpeckers and hairy woodpeckers. For all regression models, we used the same technique: stepwise forward regression was used to select important habitat predictor variables for each species. Selected variables were then placed into final complete models to ensure adequacy of fit and to avoid unstable probability values (Rexstad et al. 1990).

\section{RESULTS}

We found differences in several habitat variables among the 3 ages of forest (Table 1), despite their similar appearance and tree heights. The oldest stands were distinguished from either of the younger mature age classes by their

Table 3. Mean IPA values (number of presumed pairs) values for woodpeckers counted in stands of different ages of balsam fir forests in western Newfoundland, 1991-94. Means followed by the same letter do not differ across rows $(P>0.05 ; n=10$ stands per age class in each of $4 \mathrm{yr}$ ).

\begin{tabular}{|c|c|c|c|c|c|c|}
\hline \multirow[b]{3}{*}{ Species } & \multicolumn{4}{|c|}{ Second-growth forest } & & \\
\hline & \multicolumn{2}{|c|}{$40 \mathrm{yr}$} & \multicolumn{2}{|c|}{$60 \mathrm{yr}$} & \multicolumn{2}{|c|}{ Uncut old forest $>80 \mathrm{yr}$} \\
\hline & $\overline{\bar{x}}$ & SE & $\bar{x}$ & SE & $\bar{x}$ & SE \\
\hline Black-backed woodpecker & $0.02 \mathrm{~A}$ & 0.03 & $0.01 \mathrm{~A}$ & 0.01 & $0.43 \mathrm{~B}$ & 0.11 \\
\hline Downy woodpecker $1991-92^{a}$ & $0.43 \mathrm{~A}$ & 0.17 & $0.25 \mathrm{~A}$ & 0.12 & $0.53 \mathrm{~A}$ & 0.21 \\
\hline Downy woodpecker $1993-94^{a}$ & $1.07 \mathrm{~A}$ & 0.28 & $0.55 \mathrm{~A}$ & 0.16 & $0.80 \mathrm{~A}$ & 0.21 \\
\hline Hairy woodpecker & $0.05 \mathrm{~A}$ & 0.03 & $0.10 \mathrm{~A}$ & 0.05 & $0.0 \mathrm{~A}$ & \\
\hline Northern three-toed woodpecker & 0.03 & 0.03 & 0.0 & & 0.0 & \\
\hline
\end{tabular}

a Downy woodpecker numbers are reported in 2-year groups, as counts differed between 1991-92 and 1993-94 because of different survey techniques used. 
lower stem densities of trees, small trees, and snags, greater density of large snags, greater mean snag height and diameter, and by a more open canopy. The 40-year-old stands had a higher density of deciduous snags (primarily dead and declining white birch) than the 60- or 80-year-old stands.

We observed no differences in number of birds detected for any species between 1991 and 1992 using the point-count method, or between 1993 and 1994 using the call broadcast point-count method (Table 2; downy woodpecker ANOVA, $P>0.80$; hairy woodpecker and black-backed woodpecker, $P>0.90$ in 199192). We recorded neither of the latter species in 1994. We detected no difference between the 2 survey methods in numbers of hairy woodpeckers recorded $(U=857.5, P=0.402)$ or black-backed woodpeckers $(U=964.0, P=$ 0.439 ; with or without the zero counts from 1994). Therefore, numbers of those 2 species were compared among forest age classes for all years. However, there was a greater number of downy woodpeckers that responded to call broadcasts compared to those recorded by point counts alone $\left(F_{1,29}=6.28, P=0.023\right.$; Table 2$)$. Therefore for this species, we tested response to forest age class separately for each pair of years.

We found that black-backed woodpeckers were uncommon in all balsam fir age classes and were absent from the study area in 1994 (Tables 2 and 3). There were significantly more black-backed woodpeckers in 80-year-old forest stands compared to either of the younger age classes (Table 3; $H=27.3, P<0.001$ ). We recorded only 1 three-toed woodpecker during the 4 years. Downy woodpeckers were the most common species in balsam fir forests, and we recorded a similar number among stand age classes in 1991-92 $(P=0.309)$, and in 1993-94 (Table 3; $P=0.412$ ). Hairy woodpeckers were also uncommon, with 7 sightings during 199394 , none of which were in the 80 -year-old stands. However, we found no significant difference in numbers of hairy woodpeckers among stand age classes (Table 3; $P=0.324$ ).

Of the habitat variables (Table 1 ), only coarse woody debris was eliminated from the analysis of woodpecker response to habitat because it was correlated with snags $>20 \mathrm{~cm}$ dbh. The best linear regression model for downy woodpeckers indicated that tree density and number of dead white birch were important variables influencing habitat selection $\left(R^{2}=0.43, F_{3,26}\right.$ $=6.37, P=0.002$ ). For hairy woodpeckers, presence of the birds was related to the number of white birch snags (logistic regression; $t=$ $3.46, P<0.001$ ), and resulted in a $79 \%$ successful prediction of forest age class choice. Presence of black-backed woodpeckers was associated with 2 predictor variables: density of snags $>20 \mathrm{~cm}$ dbh (logistic regression; $t=2.68$, $P=0.007$ ), and negatively to the total number of dead stems $(t=-2.73, P=0.006)$. This model enabled a successful prediction of presence or absence of black-backed woodpeckers of $72 \%$.

\section{DISCUSSION}

Our hypothesis of greatest occurrence of all woodpecker species in the oldest forest stands was supported for black-backed woodpeckers, but appeared to be false for downy and hairy woodpeckers. Determining population density of small, widely-dispersed woodpecker populations generally has proven difficult (Amman and Baldwin 1960, Evans and Conner 1979, Spytz 1993, Virkkala et al. 1994, Hutto 1995). However, our data from 4 breeding seasons consistently showed that black-backed woodpeckers rarely occurred in balsam fir forests $<80$ years old. Therefore, we believe that reducing the availability of these old forests will result in a decline in this species in western Newfoundland. The absence of black-backed woodpeckers in our 1994 surveys concurred with observations from a longer-term study in Finland (Virkkala 1989), which indicated that resident avian species had a high variation in density among years. For a specialized species at low density, an absence may only be temporary from sites that are necessary for long-term existence (Haila 1994). A similar response by black-backed woodpeckers to forest age has been reported elsewhere, although small samples have often precluded statistical testing (Evans and Conner 1979, Helle and Järvinen 1986, Virkkala 1989, Virkkala et al. 1994, Villard 1994).

Our combined counts of black-backed woodpeckers and three-toed woodpeckers were low, but higher than those from a mixed-wood boreal forest of northeastern Ontario (IPA $=0.01$; Spytz 1993). The few observations of blackbacked woodpeckers and three-toed woodpeckers in the latter study occurred in uncut forest $\geq 70$ years of age. Evans and Conner (1979) estimated a combined density of black-backed 
and three-toed woodpecker pairs at 3.3 pairs/ $\mathrm{km}^{2}$, based on an estimated territory size of 30 ha in the northeastern United States. Exceptionally high combined densities of blackbacked and three-toed woodpeckers of $40 \mathrm{birds} /$ $\mathrm{km}^{2}$ were reported 2 years after a fire in boreal mixed-wood forest in Alaska (Murphy and Lehnhausen 1998).

Hutto (1995) concluded that the small numbers of black-backed woodpeckers in unburned forests in Montana may have occupied sink habitats, and that these populations were maintained by birds emigrating from burns when conditions became less suitable 5-6 years after a fire. In that study, black-backed woodpecker populations may have been maintained either by refuges of low numbers in unburned forests, or a patchwork of recently burned areas. In western Newfoundland, where insect defoliation replaces fire as the primary cause of stand mortality, endemic populations of black-backed woodpeckers may respond to an increase in wood-boring insect abundance in recently defoliated stands. Dead trees provide a suitable substrate for wood-boring insects up to 5 years after defoliation (Warren 1989), and weakened trees may persist several years longer. Our analyses suggested that snags related to occurrence of black-backed woodpeckers were large $(>20$ $\mathrm{cm}$ ) and probably afforded more suitable nesting and foraging substrates than would smaller trees. Black-backed woodpecker occurrence was also related to a lower number of snags in old stands compared to the higher number of snags in younger stands, suggesting it is the quality, not the number of snags, that is important. Angelstam and Mikusinski (1994) also suggested that large snags are important to certain woodpecker species. Within the last century, balsam fir forests in Newfoundland have experienced at least 8 insect defoliations of epidemic proportions that affected hundreds of thousands of hectares. Yearly endemic, localized insect defoliation events that occur throughout the balsam fir forest maintain a mosaic of 100 s of hectares in various stages of morbidity (A. Carroll, Canadian Forest Service, personal communication), after which areas of dead and dying trees provide suitable substrate for wood-boring insect larvae. The endemic defoliation events likely provide habitat that supports small populations of black-backed woodpeckers between severe outbreaks. Therefore, we believe that the quality of the old-growth balsam fir forest hab- itat to black-backed woodpeckers varies among years, depending on the level of attack by insects.

Our stand age classes differed structurally from each other, and several stand characteristics were related to use by individual woodpecker species. Use of younger mature stands by downy and hairy woodpeckers was affected by the higher densities of white birch snags in these stands than in older stands. On our study area, white birch often becomes established in forests following harvesting, but dies out once the dominant balsam fir reaches maturity and shades the birches (Meades and Moores 1989). Many white birch trees had fallen by 60 years of age, and the species was virtually absent in our old forests. Other studies from eastern North American forest types showed that downy woodpeckers and hairy woodpeckers are associated with a variety of mixed species and hardwood forest types (Erskine 1977, Thompson and Capen 1988, Derleth et al. 1989, Welsh and Lougheed 1996), and that white birch provides a favored feeding substrate (Kilham 1970). Welsh and Capen (1992) suggested that availability of nesting sites did not limit downy or hairy woodpecker abundance in older hardwood forests of the northeastern United States. However, the scarcity of hairy woodpeckers in our study likely reflected their requirement for higher densities of hardwood trees as substrates for foraging and nesting than occurred in Newfoundland balsam fir-dominated stands.

Downy woodpeckers were more abundant in balsam fir forests of Newfoundland than in mixed spruce-fir-aspen-birch stands in northeastern Ontario (IPA = 0.03; Spytz 1993), similar to densities in intolerant hardwood forests of Prince Edward Island (IPA $=0.20$ ), but less than in thinned 50 to 100 -year-old tolerant hardwood stands on the same study (IPA = 0.43; Sabine and Makepeace 1990). Hairy woodpeckers were less abundant in our balsam fir forests than in the mixed forests of northeastern Ontario or in tolerant hardwood stands of Prince Edward Island (Sabine. and Makepeace 1990). Downy woodpeckers and hairy woodpeckers would probably be unaffected by shortened harvest rotations in balsam fir forests, assuming a residual standing hardwood component remains following harvesting.

\section{Recommendations for Future Research}

To determine the abundance of woodpeckers, we recommend that transects and point 
counts be used together. Observers should walk transects with a minimum length of $1 \mathrm{~km}$, periodically stopping at promising locations (e.g., signs of recent feeding, or at groups of trees in various stages of morbidity) to broadcast woodpecker calls. This method has proved to be efficient for locating red-breasted sapsuckers (Sphyrapicus ruber), hairy woodpeckers, and northern flickers in Douglas-fir (Pseudotsuga menziesii)-western hemlock (Tsuga heterophylla) forests and forest edges on northern Vancouver Island, British Columbia, Canada (M. A. Setterington, AXYS Environmental Consulting, unpublished data). Density can be estimated from variable-width transects for which robust sampling methods are available (Buckland et al. 1993). A sample of transects should be surveyed with all woodpeckers heard and their perpendicular distance to the transect recorded. Transect width would not be fixed, but observers should decide a maximum distance at which to truncate observations as a final distance class, because of excessive time locating distant birds and returning to the transect line. However, such surveys must be extensive to gain an adequate sample of each species of woodpecker because of large home ranges. Observers should look for signs of recent woodpecker activity as well as birds. Areas of recent or old feeding and nesting activity are preferred locations for broadcasting calls to attract silent woodpeckers. Stopping and listening for the faint tapping of an excavating or feeding woodpecker will often facilitate detection of woodpeckers that may be missed if the observer continuously walks transects. However, Verner (1986) concluded that because of the low abundance of pileated woodpeckers (Dryocopus pileatus) in northwestern United States, total costs would exceed $\$ 1,000,000 /$ year to detect a $10 \%$ change (with 95\% confidence) in numbers from random sampling between years. The same effort would likely be required for intensive surveys of blackbacked and hairy woodpeckers in Newfoundland.

Nest searches could also be used as an inventory method of woodpecker use of forests. Although labor-intensive, number of nests provides a measure of absolute density of breeding woodpeckers. Further, establishing nesting success by monitoring nests can provide evidence of relative fitness of woodpeckers in various habitat types or ages of forests. For example, $\mathrm{Li}$ and Martin (1991) used a simple index of nest- ing success to suggest fitness of woodpeckers in relation to nest site features.

Understanding the spatial distribution and amount of suitable habitat on a landscape is essential to understanding woodpecker population dynamics (Dunning et al. 1995, Turner et al. 1995). Some woodpecker species need large areas, with old-growth properties, because of their relatively large body size and large home ranges, but may be able to use groups of smaller patches spread across a landscape (Dunning et al. 1992, Angelstam and Mikusinski 1994) if suitable patches are not excessively small or dispersed (Virkkala 1991, Bull and Holthausen 1993, Virkkala at el. 1994). Therefore, studies are required of sufficient duration (7-10 yr) and on a scale that can provide reliable information of age of reproduction, survival rates, and juvenile dispersal and population turnover (Verner 1992). Large scale and long time periods of study would enable assessment of optimal and suboptimal habitats to determine how populations maintain themselves as relative availabilities of these habitats change. For example, in much of North America, fire suppression efforts over the past 50 years may have altered longterm population dynamics of species, such as black-backed woodpeckers, that respond numerically to transient habitats created by fires in old forests.

\section{MANAGEMENT IMPLICATIONS}

Black-backed woodpeckers are found consistently in the oldest conifer forest types, except when recently burned areas are available. In western Newfoundland, their unique occurrence in old forests probably reflects availability of large cavity trees that were only available in these late successional stands. Setterington (1997) reported that nest sites were in large snags located in relatively open areas. Such areas were typical of sites resulting from small insect defoliation outbreaks or blowdowns typical of old balsam fir forests. Under a short-rotation management regime, such habitat would become even more rare than at present, especially in intensively managed, pre-commercially thinned forests. Although costly, it may be possible to mimic small endemic insect infestation in pre-commercially thinned, second-growth forests by killing small numbers of trees by girdling (at least 100 stems/ha, or about $4-5 \%$ of the trees in a stand), when the stand reached 50 years of age, to provide sources of food and 
nesting substrates for black-backed woodpeckers. Further, maintaining white birch trees in managed stands rather than eliminating them, as is the current practice during thinning operations, would support future populations of hairy and downy woodpeckers when these forests grow to maturity.

While it is difficult to provide an operational definition of a snag because it may be variable for each woodpecker species (Carey 1983), there is sufficient information to suggest that forest managers should focus on landscape and stand features that affect woodpecker populations and distribution, rather than on requirements for minimum viable populations (Probst and Crow 1991). The most effective method to ensure ample black-backed woodpecker nesting habitat is to exempt certain large old-forest areas across a landscape from commercial, or post-insect defoliation salvage harvesting on a temporally rotating basis (Goggans et al. 1988). In Newfoundland, managers should assume that eradication of old balsam fir forests will affect the persistence of black-backed woodpeckers and other forest interior birds (Thompson et al. 1999), and therefore include old forests in landscape planning and management modeling to avoid loss of biological diversity (Thomas et al. 1988, Thompson and Welsh 1993).

\section{ACKNOWLEDGMENTS}

H. A. Hogan generously provided us with woodpecker data from 1991 and 1992. B. Mactavish collected bird and habitat data in all 4 years of this study, and W. J. Curran provided technical assistance in the collection of habitat data. Our project was supported by funding from Canadian Forest Service, Green Plan, Forestry Practices Initiative. Corner Brook Pulp and Paper aided in the location of forest stands.

\section{LITERATURE CITED}

Amman, G. D., AND P. H. Baldwin. 1960. A comparison of methods for censusing woodpeckers in spruce-fir forests of Colorado. Ecology 41:699706.

ANDERSON, S. H., AND K. I. GUTZWILlER. 1994. Habitat evaluation methods. Pages 592-606 in T. A. Bookhout, editor. Research and management techniques for wildlife and habitats. The Wildlife Society, Bethesda, Maryland, USA.

AngelstaM, P., AND G. Mikusinski. 1994. Woodpecker assemblages in natural and managed boreal and hemiboreal forest-a review. Annales Zoologica Fennici 31:157-172.

BAKUZIS, E. V., AND H. L. HANSEN. 1965. Balsam fir: a monographic review. University of Minnesota Press, Minneapolis, Minnesota, USA.

BANFIELD, C. E. 1983. Climate. Pages 37-106 in G. R. South, editor. Biogeography and ecology of the Island of Newfoundland. Junk Publishers, Hague, Netherlands.

BAtCheleR, C. L. 1975. Probable limit of error of the point-distance neighbour estimate of density. Proceedings of the New Zealand Ecological Society 22:28-33.

Bibby, C. J., N. D. Burgess, AND D. A. Hill. 1992. Bird census techniques. Academic Press, London, England.

Blondel, J., C. Ferry, and B. Frochot. 1981. Point counts with unlimited distance. Studies in Avian Biology 6:414-420.

Bock, C. E., AND J. H. BoCK. 1974. On the geographical ecology and evolution of the three-toed woodpeckers, Picoides tridactylus and P. arcticus. American Midland Naturalist 92:397-405.

Buckland, S. T., D. R. Anderson, K. P. Burnham, AND J. L. LAAKE. 1993. Distance sampling: estimating abundance of animal populations. Chapman \& Hall, New York, New York, USA.

Bull, E. L., AND R. S. Holthausen. 1993. Habitat use and management of pileated woodpeckers in northeastern Oregon. Journal of Wildlife Management 57:335-345.

CAREY, A. B. 1983. Cavities in trees in hardwood forests. Pages 167-184 in J. W. Davis, G. A. Goodwin, and R. A. Ockenfels, editors. Snag habitat management: proceedings of the symposium. U.S. Forest Service General Technical Report RM-99.

Damman, A. W. H. 1983. An ecological subdivision of the Island of Newfoundland. Pages 163-206 in G. R. South, editor. Biogeography and ecology of the Island of Newfoundland. Junk Publishers, Hague, Netherlands.

DAY, R. W., AND G. P. QUINN. 1989. Comparisons of treatments after analysis of variance in ecology. Ecological Monographs 59:433-463.

DAwson, D. G. 1981. Counting birds for a relative measure (index) of density. Studies in Avian Biology 6:12-16.

Derleth, E. L., D. G. MCAuley, and T. J. DWyer. 1989. Avian community response to small-scale habitat disturbance in Maine. Canadian Journal of Zoology 67:385-390.

Draper, N. R., AND H. Smith. 1981. Applied regression analysis. John Wiley \& Sons, New York, New York, USA.

Dunning, J. B., B. J. Danielson, and H. R. PulLIAM. 1992. Ecological processes that affect populations in complex landscapes. Oikos 65:169175.

, D. J. Stewart, B. J. Danielson, B. R. NOON, T. L. ROOT, R. H. LAMBERSON, AND E. E. Stevens. 1995. Spatially explicit population models: current forms and future uses. Ecological Applications 5:3-11.

ELLISON, W. G. 1992. Different drummers: identifying the rhythms of northeastern woodpeckers. Birding 24:350-355.

Erskine, A. J. 1977. Birds in boreal Canada: com- 
munities, densities and adaptations. Canadian Wildlife Service Report Series Number 41.

Evans, K. E., AND R. N. Conner. 1979. Snag management. Pages 214-225 in R. M. DeGraaf and K. E. Evans, editors. Management of north central and northeastern forests for nongame birds. U. S. Forest Service General Technical Report NC-51.

Goggans, R., R. D. Dixon, AND L. C. SEminara. 1988. Habitat use by three-toed and black-backed woodpeckers, Deschutes National Forest, Oregon. Oregon Department of Fish and Wildlife Nongame Report No. 87-3-02.

HaIla, Y. 1994. Preserving ecological diversity in boreal forests: ecological background, research, and management. Annales Zoologica Fennici 31:203217.

Haney, J. C., AND C. P. SchaAdT. 1996. Functional roles of eastern old growth in promoting forest bird diversity. Pages 76-88 in M. B. Davis, editor. Eastern old growth forests: prospects for rediscovery and recovery. Island Press, Washington, D.C., USA.

Helle, P., AND O. JärVInen. 1986. Population trends of north Finnish land birds in relation to their habitat selection and changes in forest structure. Oikos 46:107-115.

HuTto, R. L. 1995. Composition of bird communities following stand-replacement fires in northern Rocky Mountain (U.S.A.) conifer forests. Conservation Biology 9:1041-1058.

Johnson, R. R., B. T. Brown, L. T. Haight, AND J. M. SIMPSON. 1981. Playback recordings as a special avian censusing technique. Studies in Avian Biology 6:68-75.

KAUFMAN, K. 1993. Identifying the hairy woodpecker. American Birds 47:311-314.

KilHAM, L. 1970. Feeding behavior of downy woodpeckers I. Preference for paper birches and sexual differences. Auk 87:44-556.

Leverett, R. 1996. Definitions and history. Pages 317 in M. B. Davis, editor. Eastern old-growth forests: prospects for rediscovery and recovery. Island Press, Washington, D.C., USA.

LI, P., AND T. E. MARTIN. 1991. Nest-site selection and nesting success of cavity-nesting birds in high elevation forest drainages. Auk 108:405-418.

Mactavish, B., J. E. Maunder, W. A. MontevecCHI, AND J. L. WELLS. 1999. Checklist (1999) of the birds of insular Newfoundland and its continental shelf waters. Natural History Society of Newfoundland and Labrador, St. John's, Newfoundland, Canada.

Marion, W. R., E. O'Meara, and D. S. Maehr. 1981. Use of playback recordings in sampling elusive or secretive birds. Studies in Avian Biology 6:81-85.

MCComb, W.C., S. A. Bonney, R. M. ShefField, AND N. D. Cost. 1986. Snag resources in Flori$\mathrm{da}$-are they sufficient for average populations of primary cavity nesters? Wildlife Society Bulletin 14:40-48.

McRae, D. J., M. E. Alexander, and B. J. Stocks. 1979. Measurement and description of fuels and fire behaviour on prescribed burns: a handbook. Canadian Forest Service Report 0-X-287.
Meades, W. J., AND L. Moores. 1989. Forest site classification manual: a field guide to the Damman forest types of Newfoundland. Forestry Canada and Newfoundland Department of Forestry and Agriculture, Forest Resources Development Agreement Report Number 003.

Mosher, J. A., M. R. Fuller, AND M. Kopeny. 1990. Surveying woodland raptors by broadcast of conspecific vocalizations. Journal of Field Ornithology 61:453-461.

Murphy, E. C., AND W. A. Lehnhausen. 1998. Density and foraging ecology of woodpeckers following a stand-replacement fire. Journal of Wildlife Management 62:1359-1372.

PRobst, J. R., AND T. R. Crow. 1991. Integrating biological diversity and resource management. Journal of Forestry 89:12-17.

Rexstad, E. A., D. D. Miller, C. H. Flather, E. M. Anderson, J. W. Hupp, AND D. R. AnderSON. 1990. Questionable multivariate statistical inference in wildlife habitat and community studies: a reply. Journal of Wildlife Management 54: 189-193.

RowE, J. S. 1972. Forest regions of Canada. Canadian Forest Service Publication No. 1300.

SAbine, D. L., AND S. MaKePeace. 1990. Surveys of breeding bird communities in managed and unmanaged forests stands on Prince Edward Island. Forestry Canada, Forest Resource Development Agreement Report No. 006.

SETTERINGTON, M. A. 1997. Woodpecker abundance and nest habitat in a managed balsam fir ecosystem. Thesis, Memorial University, St. John's, Newfoundland, Canada.

SHORT, L. L. 1982. Woodpeckers of the world. Delaware Museum of Natural History, Greenville, Delaware, USA.

SPYTZ, C. P. 1993. Cavity-nesting-bird populations in cutover and mature boreal forest, northeastern Ontario. Thesis, University of Waterloo, Waterloo, Ontario, Canada.

Thomas, J. W., R. G. Anderson, C. Maser, and E. L. Bull. 1979. Snags. Pages 60-77 in J. W. Thomas, editor. Wildlife habitats in managed forests of the Blue Mountains of Oregon and Washington. U.S. Department of Agriculture Forest Service, Agricultural Handbook 553.

-, L. F. Ruggiero, R. W. Mannan, J. W. SChOEN, AND R. A. LANCIA. 1988. Management and conservation of old-growth forests in the United States. Wildlife Society Bulletin 16:252262.

Thompson, D. R., AND D. E. CAPEN. 1988. Avian assemblages in seral stages of a Vermont forest. Journal of Wildlife Management 52:771-777.

Thompson, I. D. 1991. Could marten become the spotted owl of eastern Canada? Forestry Chronicle 67:136-140

, AND W. J. CURRAN. 1995. Habitat suitability for marten of second-growth balsam fir forests in Newfoundland. Canadian Journal of Zoology 73: 2059-2064.

, H. A. Hogan, and W. A. Montevecchi. 1999. Avian communities of mature balsam fir forests of Newfoundland: age-dependence and implications for harvesting. Condor 101:311-323. 
AND D. A. WELSH. 1993. Integrated resource management in boreal forest ecosystems-impediments and solutions. Forestry Chronicle 69:3239.

Turner, M. G., G. J. Arthaud, R. T. Engstrom, S. J. HeJl, J. LiU, S. LOeb, AND K. MCKelvey. 1995. Usefulness of spatially explicit population models in land management. Ecological Applications 5:12-16.

VAN HoRne, B. 1983. Density as a misleading indicator of habitat quality. Journal of Wildlife Management 47:893-901.

VERnER, J. 1986. Future trends in management of nongame wildlife: a researcher's viewpoint. Pages 149-171 in L. B. Best and R. L. Clawson, editors. Management of nongame wildlife in the midwest: a developing art. Forty-seventh Midwest Fish and Wildlife Conference, Grand Rapids, Michigan, USA.

1992. Data needs for avian conservation biology: have we avoided critical research? Condor 94:301-303.

VILLARD, P. 1994. Foraging behavior of black-backed and three-toed woodpeckers during spring and summer in a Canadian boreal forest. Canadian Journal of Zoology 72:1957-1959.

VILLARD, P., AND C. W. BENINGER. 1993. Foraging behavior of male black-backed and hairy woodpeckers in a forest burn. Journal of Field Ornithology 64:71-76.

VIRKKALA, R. 1989. Short-term fluctuations of bird communities and populations in virgin and managed forests in northern Finland. Annales Zoologica Fennici 26:277-285.

. 1991. Population trends of forest birds in a Finnish Lapland landscape of large habitat blocks: consequences of stochastic environmental variation or regional habitat alteration? Biological Conservation 56:223-240.

VirkKala, R., A. RajasärkKä, R. A. VÄISÄNen, M.
ViCKHOLM, AND E. Virolainen. 1994. Conservation value of nature reserves: do hole-nesting birds prefer protected forests in southern Finland? Annales Zoologica Fennici 31:173-186.

WARREN, G. R. 1989. The identities, roles, and interactions of the fungi associated with stem biodeterioration of balsam fir stressed and killed after spruce budworm defoliation in Newfoundland. Dissertation, State University of New York, College of Environmental Science and Forestry, Syracuse, New York, USA.

Welsh, C. J. E., AND D. E. CAPEN. 1992. Availability of nesting sites as a limit to woodpecker populations. Forest Ecology and Management 48:31-41.

Welsh, D. A., AND S. C. LougheEd. 1996. Relationship of bird community structure and species distributions to two environmental gradients in the northern boreal forest. Ecography 19:194208.

WhitaKer, D. M., AND W. A. MontevecChI. 1997. Breeding bird assemblages associated with riparian, interior forest, and nonriparian edge habitats in a balsam fir ecosystem. Canadian Journal of Forest Research 27:1159-1167.

Winkler, H., D. A. Christy, AND D. BuRNeY. 1995. Woodpeckers: a guide to the woodpeckers of the world. Houghton Mifflin Company, Boston, Massachusetts, USA.

Wood, G. W., L. J. Niles, R. M. HendRick, J. R. DAVIS, AND T. L. GRIMES. 1985. Compatibility of even-aged management and red-cockaded woodpecker conservation. Wildlife Society Bulletin 13: 5-17.

YUNICK, R. P. 1985. A review of recent irruptions of the black-backed woodpecker and three-toed woodpecker in eastern North America. Journal of Field Ornithology 56:138-152.

Received 22 March 1999.

Accepted 23 September 1999.

Associate Editor: Sullivan. 